\title{
Pain, Partum and Prayer: The Dis-ease of Motherhood in Early Modern English Literature
}

\author{
Namrata Chaturvedi \\ Associate Professor, Department of English, SRM University, Sikkim. \\ Email: namratachaturvedi.v@srmus.edu.in
}

\begin{abstract}
This paper is a close study of early modern women's poetry on childbirth and the imminent circumstances of maternal and foetal/infantile mortality in seventeenth century England. In tracing the development of women's post-partum mental health from the medieval to the early modern period, this paper argues for a serious investment in literature composed as memoirs, poetry, diaries and funeral sermons as a means of understanding the trajectories and lacunae in women's mental health in the early modern period. This study also argues for including the religious experience into any consideration of women's post-partum health and therapeutic interventions. Lastly, it shows how affect studies have proved the recuperative potential in literature of consolation and mourning so that women's writing begins to get recognized for its interventionist potential rather than a fossilized historical treatment as it has often received.
\end{abstract}

Keywords: Partum, Early Modern, Women, Mental Health, England

\section{Introduction}

"Thine almightie wisdom and power is manifest unto us in all thy works, but most chieflie in the
wonderfull worke of the forming of man, who of a marvelous small and loathsome substance, is
made a living creature".
Thomas Bentley: Monument of Matrones, p.101

The Protestant reformer Thomas Bentley thus described the birth of a child as being made of "a small and loathsome substance", the human sperm, in the book of prayers he compiled for Christian women in late sixteenth century. Mary E Fissell (2004) ${ }^{\mathrm{i}}$ has noted how the focus of childbirth shifted from an innately feminine poetic to masculine poetic in the post Reformation period. From medieval English mysticism, we find miracles and charms associated with childbirth wherein women were encouraged to identify their experience with Marian partum asking for mercy, help and inspiration from the figure of Mother Mary. It is with post Reformation emphasis on identification and supplication to Christ that the tenor of poetic tropes and theological tracts shifts primarily to the masculine godhead and women being urged to identify the partum agony with Eve and her sinfulness. In tracing early medical literature on partum, we find this Catholic to Protestant shift with some exceptions of female theologians like Aemilia Lanyer and Dorothy Leigh ${ }^{\text {ii }}$ (in the seventeenth century) establishing that Western women's emotional health in the context of partum has always remained deeply embedded in the religious experience.

In post Reformation vocabulary, we begin to notice another major transition. Women's bodies begin to assume a clinical existence with parturition being recognized as a biological process, rather than a spiritual one $\mathrm{e}^{\mathrm{iii}}$. This transition forms the basis of modern medical literature which

(c) AesthetixMS 2021. This Open Access article is published under a Creative Commons Attribution Non-Commercial 4.0 International License (http://creativecommons.org/licenses/by-nc/4.o/), which permits non-commercial re-use, distribution, and reproduction in any medium, provided the original work is properly cited. For citation use the DOI. For commercial re-use, please contact editor@rupkatha.com. 
recognizes this physical process and even tries to subvert and transcend its limitations through laboratorial interventions. In this paper, I intend to examine English literary historiography from medieval to early modern period by highlighting the work of select women writers whose experiences and personal expressions invite us to deeply reflect on postpartum mental health in circumstances of birth, miscarriage, stillbirth and infertility.

It is a fact universally assumed that motherhood is a blessing. It is also conveniently considered as the summum bonum of a woman's existence and uncritically projected as a linear narrative worthy of glorification. The lacunae in this narrative, though too obvious, are socially and culturally ironed out by subsuming individuality within a collective moral quotient. These lacunae consist of psychological transformation brought about by anxiety, fear and the experience of pain. There are also blank spots in this narrative that are brought about by infertility, miscarriage, infant mortality and a much neglected aspect- maternal mortality. The dis-ease of motherhood is a fact known to all societies and cultures, yet the study of the different paradigms of this universal disease and ways of recovery have largely been outsourced to disciplines such as psychology and public health. In literature, we find rich meditative work focusing on this dis-ease, written by women who were dealing with their individual traumas but fostering a sisterhood of consolation poetry.

In this paper, I attempt to draw attention to these works in English ranging from the medieval to the early modern period These writers have often slipped away from invested poetic studies and even renewed literary interest in research has relegated them to genres as limiting as 'mother's elegy' or 'child loss poetry'. As a discipline, as medical humanities has begun to recognize the spiritual agency of mothers and children as transformative and healing, there is a need to appreciate the poetic and spiritual quotient of poems written by mothers possessed by the fear of partum death leaving behind verses for their husbands and children, of mothers (and fathers) consoling themselves of deaths of their children in and outside the womb, and of mothers trying to make sense of partum itself. In literary studies, one finds sustained interest in women's elegies, the poetics of maternal elegies as a subgenre, exploration of public and private spheres of writing and mourning and analyses of the relationship between patriarchy and religion in confining and deciding women's bodily experiences ${ }^{\text {iv }}$. Along with these studies that have shaped critical discourse in the last two decades, it will also be rewarding to further explore the psychological dimensions of emotional wellbeing through an appreciation of piety and devotion as not necessarily oppressive. The poetic expressions of partum invite us to consider inherent potential even in the conventional tropes of mysticism and piety themselves, as personalized spirituality is a powerful tool in emotional negotiations and therapy ${ }^{\mathrm{v}}$.

\section{The Book of Post-Partum Depression}

In England, the end of the thirteenth century marks the figure of Margarey Kempe, probably writing c. $129 \mathrm{o}^{\mathrm{vi}}$, a figure central to medieval English mysticism. The British Library has digitized the only extant copy of her autobiography, also believed to be the first autobiography written in English. In it, referring to herself in the third person ("this creatur"), Kempe has recorded her trials of life and her conversations with god. The Book of Margarey Kempe records her illness following the birth of her first child, her feeling threatened by devils, being forcibly restrained and biting her own hand leaving an indelible mark for the rest of her life. The book then records that Jesus appeared to her in a vision and she found calmness. This fourteenth century (or thirteenth) account of a woman struggling to find spiritual peace through the phase of childbirth and its after effects is an important literary mode that gets prominence in the seventeenth century in the form of devotional elegies. In 
more recent times, many books have begun to appear that recognise and address the dynamics of the spiritual effects of pregnancy and childbirth (and child loss) on women. Kempe is therefore often hailed as a feminist icon and social reformer, along with her personalised mysticism, foregrounding prayer and intimate spiritual experiences as an integral part of postpartum health.

In her accounts regarding her illness during and after the birth of her first child (she is believed to have delivered fourteen, not all of whom survived), she called for a priest anticipating death, found it unable to confess as the priest left before she could lighten her conscience. This led to a fear of eternal damnation in her, and then ensued a period of physical constraints ${ }^{\mathrm{vii}}$, psychosis, fits, as they have been variously described. It is obvious that these are unrefined descriptions of post partum depression, a spiritual malady that is now a part of modern medical discourse. Kempe's tormented spirit that then devoted itself to the service of Christ finds echo in Mary Carey and An Collins two centuries later.

The complete manuscript of Kempe's The Book of Margarey Kempe was discovered in the 1930s. Following this, the initial reception was skeptical, considering her as psychologically ill rather than a true mystic. In the critical studies on Kempe, Atkinson and Lochrie have turned the debate from the authenticity of Kempe's mystical experience viii to the social and unconventional dimensions of her writing strategies. The spiritual malady of a married woman and a mother finds echo in the poetry of women in the seventeenth century. Kempe's spiritual crisis is the crises of many women who are trying to negotiate between a dedicated religious life and an engaged worldly life, conforming to the social and interpersonal demands of 'womanhood' $\mathrm{ix}$.

Kempe's autobiography holds promise for an invested study from the perspective of health humanities. In the situation of acute postpartum depression, Kempe's intimate conversations with Christ at her bedside and her subsequent moderation and piety along with a later fulfilling married life and healthy partum experiences highlight the therapeutic potential of spiritual intimacy, something that medical research has lately been waking up to ${ }^{\mathrm{x}}$. Proliferation of wellness books on 'Spiritual Pregnancy' lately point to the fact that this inherently spiritual experience has inbuilt spiritual dimensions which are the core concepts in wellbeing and therapy.

\section{Confinement to Bed}

In the seventeenth century, the meditative verse of An Collins is important for scholars interested in the relationship between sickness, spatial confinement and wellbeing in the early modern period. An Collins was a poet, living and writing in the seventeenth century. Her biographical details can only be gleamed and estimated from her single book titled Divine Songs and Meditacions published in 1653. Sidney Gottlieb ${ }^{\mathrm{xi}}$ has done important work in restoring an interest in her poetry by editing, and writing an Introduction for her work in 1996. Since then, some remarkable scholarly work has been done on her poetry, the most recent by Howard (2014), described as the first edited collection of scholarly essays to focus exclusively on this 'important religious and political poet from seventeenth century England'. In his introductory essay titled 'Imagining An Collins', Howard points out that a single manuscript of her book survives in The Huntington Library, USA. No details regarding the dates of her birth or death, her family, her education etc are available. In a 2001 study edited by Jane Stevenson and Peter Davidson, An Collins has been portrayed as:

unmarried, probably of 'the middling sort' and a chronic invalid from her childhood... In "The Discourse" she states that her family was (at least by her own standards in later life) 
worldly and frivolous, so that in her youth, she had access to fiction, which she greatly enjoyed. At some point, she experienced a personal religious conversion, and rejected these "profane Histories" in favor of prayer and meditation. It is clear that she was a diligent reader of the Bible, and probably of contemporary Christian writings. ${ }^{\mathrm{xii}}$

An Collins finds no mention in the reputed poetry anthologies of seventeenth, eighteenth and early nineteenth centuries. Howard points out to her absence from The Harmonyy of the Muses (1654), The Marrow of Complements (1654), Parnassus Biceps (1656), Aphra Behn's Poems upon several occasions...To which is added a miscellany of new poems and songs, by several hands (1685), Edward Philips's Theatrum Poetarum (1675), Poems by Eminent Ladies (1755), Reliques of Ancient English Poetry (1765), George Ellis's Specimens of the Early English Poets (1803) and Horatio Walpole's A Catalogue of the Royal and Noble Authors of England, Scotland, and Ireland (1806). It was with the appearance of selections from Collins's "Divine Songs" in Griffith's Bibliotheca AngloPoetica (1815), Brydges's Restituta (1815), Dyce's Specimens of British Poetesses (1825) and Rowton's The Female Poets of Great Britain (1849) that An Collins began to register presence in the ideas concerning sacred poetry in seventeenth century England. Two of the four anthologies mentioned above are however dedicated to 'women writers'. Collins' reputation also gained when James Montgomery selected (even though he casually rearranged) twelve lines from her divine songs in his famous Gleanings from the Sacred Poets (1875). In 1921, Sir John Collings Squire edited a volume A Book of Women's Verse in which he included two poems of Collins. In this volume, Squire outlined the tradition of lyric poetry from Drummond of Hawthornden (1585-1649) to Frances Greville (1724-1789) that would include (Mrs.) Taylor, Aphra Behn, Ephelia, An Collins and Mary Oxlie. In the 1980 os renowned anthologies as Germaine Greer's Kissing the Rod and Elspeth Graham's Her Own Life are seen to feature Collins's work.

In placing An Collins in the tradition of devotional lyric in seventeenth century England, critics have identified the influence of Herbert on her poetry, and have also undertaken comparative readings. Thomas Healy in New Latitudes: Theory and English Renaissance Literature (1992), comparing Collins and Herbert says: "Collins's expression of self-effacing is better than Herbert's in the sense that [her] humility is paramount" while Herbert maintains "a strong concept of self, and, indeed, self-applause". Richard Strier in "Lyric poetry from Donne to Philips"xiii says of Collins [that she] "brings a powerful intellectual grasp of Calvinist theology to bear on the details of her own psychological experience."

In Kissing the Rod, she is introduced, with the rider that not much is known of her biographical details, therefore extrapolation from her extant writing shows:

From 'To the Reader', the 'Preface' and 'The Discourse' we learn that, when she sent her book to the printer, the poet was childless and entering on middle age, having been chronically ill since childhood. Prose meditations included in the volume reiterate the theme of resignation to the will of God in order to overcome mental and physical suffering. Unable to participate in normal female employments she turned first to 'prophane Histories' and then to 'Theological employments' in the form of poetry. From her devotional reading, and her 'Song composed in time of Civill Warr, when the wicked did much insult over the godly' we believe that if not actually a Catholic, she was devoutly anti-Calvinist. ${ }^{\text {xiv }}$

In lines as "Yet sith it was my morning exercise, The fruit of intellectuals to vent", Greer identifies the direct influence of the Salesian ${ }^{\mathrm{xv}}$ practices of meditation where the "morning exercise" was considered as the first step to the practice of meditation. 
In Divine Songs and Meditations we witness the spiritual trials and consolations of a womansick, suffering and trying to console herself for the lack of a 'womanly' ${ }^{x v i}$ existence. In the following lines, Collins develops on the imagery of 'the enclosed garden' popular in religious writing, representing the Church (the spouse), and often the individual soul in women's religious poetry. From the Canticles 4:12: "A Garden inclosed is my sister, my spouse; a spring shut up, a fountain sealed"xvii

\section{Luis de la Puente wrote that Solomon}

twice calleth her [the Spouse] an inclosed garden, for that she was perfectly chaste both in soule, and in body, confirming it with a perpetuall vowe, which served as a locke for her greater security; adding for gardes, humility, modesty, silence, and abstinence, by reason whereof hee also calleth her a garden: to give us to understand, that her virginity was not barren, but accompanied with many flowers of vertues. ${ }^{\text {viii }}$

Yet as a garden is my mind enclosed fast

Being to safety so confind from storm and blast

Apt to produce a fruit most rare,

That is not common with every woman

That fruitfull are.

A Love of goodnesse is the chiefest plant therein

The second is, (for to be briefe) Dislike to sin.

These grow in spight of misery,

Which Grace doth nourish and ease to flourish

Continually ${ }^{\mathrm{xix}}$.

An Collins' poetry is a central example of Protestant poetics that relied heavily on typological Biblical hermeneutics ${ }^{\mathrm{xx}}$. An Collins' avowed inability to completely realize her 'womanhood' due to chronic illness and consequent inability to enter matrimony and motherhood compel us to examine the 'feminine question' in early modern period. Her writing offers us two important paradigms. Firstly, it invites us to question the relationship between gender and body performance, an idea that the third wave feminism has investigated closely. Secondly, it highlights domestic Protestant theology in early modern England, an area of study that still offers much scope. It invites us to examine the experiences and expressions of conversion by women in sickness, suggesting a liberating potential embedded in sickness itself. Domestic (feminine) theology finds its prototype in Margarey Kempe and Sister Julian's writings in the medieval period, and through the work of An Collins, we find points of entry into this promising field of inquiry in literature. While in the seventeenth century, we engage with motifs of illness and pain in the poetry of George Herbert, we must bring in the ill female subject too, at least in comparative frameworks to mark the differences between public theology as of Herbert and domestic theology of women like An Collins. 


\section{'Mother's Elegy': Childbirth and Mortality}

Experiences of the body were poignant for women in this period as life expectancy was low, and death in child birth and loss of children owing to high mortality amongst infants young children were common in this period ${ }^{x x i}$. Helen Wilcox points out: "The combination of devotional selfconsciousness and the likelihood of early death made the seventeenth century, through this cruelly ironic juxtaposition, the great age of the devotional elegy." ${ }^{x i i}$. A whole genre of mother's legacy became popular in seventeenth century England, as these texts sought to teach and posthumously engage in a dialogue with children in the likelihood of prospective death in childbirth. This possibility also became, for many women, models on which they could base their writings and hope to be accepted in a male dominated world. Some important works in this tradition are Dorothy Leigh's The Mother's Blessing (1616) and Elizabeth Jocelin's The Mothers Legacie, To her unborne Childe (1624)

In the context of maternal elegy, the writings of Lady Carey are of much significance. Mary Carey (1609-80) was the author of "my Lady Carey's Meditation, \& Poetry". She wrote in the tradition of what has been variously termed as child-loss poetry, devotional elegy, and conversion narratives. In her prose and poetry, the theme of child loss bears heavily, while the writings try to find ways of understanding the ways of god.

Mary Carey suffered the death of five of her children and a loss of child in her womb. She married twice; of her first marriage, one child survived, and of the second, two. She writes:

I want not that desired Mercy of children; but have now more than ever; One was my greatest number formerly and all my Children were only Children; each Child when it died; was all I had alive: Now great, \& tender Mercy gives, \& continues me two, a Son \& a Daughter, all my former were sickly, weake, pained, not likely to live; but these have been, \& are healthfull, strong, enjoying Ease, hopefull; blessed be God for Bethia and Nathaniel...xxiii

Her A Dialogue Betwixt the Soul and the Body (1649 ms) deploys the familiar trope of the body and soul engaging in a series of dialogues, trying to understand and accept the harsh fate of her life. In the Dialogue, the body complains that god had taken her son away from her, to which the soul replies: "First, For the removal of the Child, know, that it is Gods Will, to which submit, not one word; and do not onely yield, but approve; God is wise and knows it best; God is loving, and therefore did it"xxiv. Carey's "written by me at the death of my $4^{\text {th }}$ sonne and $5^{\text {th }}$ Child Perigrene Payler" and "Upon ye Sight of my abortive Birth" are consolatory poems written to fill up the spiritual void that the death of a child would create in a parent. The following lines from "Wretten by me..." are the attempts of a spiritually broken mother to grapple with the successive deaths of her children:

I thought my all was given before

but mercy ordred me one more:

A Perigrene; my God me sent

him back againe I doe present

As a love token;'amongst my others,

One daughter; and hir 4 deare Brothers:

To my lord Christ; my only bless; 
Ii, he is mine; and I am his

My Dearest lord; hast thou fulfill'd thy will, thy hand maid's pleas'd, Compleatly happy still:

Through Carey's poetry, one gets to focus on maternal therapy, an often neglected aspect of the spiritual life of women in the seventeenth century. The loss of life that is supposed to sustain itself within one's body can only be imagined for the kind of bearing it can have on the spiritual make up of a woman. The consolations and explaining the 'ways of god' to herself are the foundations of the devotional temper of women, trying to understand the relationship between the body and soul. In this context, the relationship becomes more complex, as the trial is of understanding the loss of soul through one's body, the thwarted arrival of another soul into the world through the channel of one's own body. While tracts and prayers ${ }^{\mathrm{xxv}}$ were popularly available for preparing women for partum and even childrearing in this period, we do not find the prevalence of missed birth literature, preparing women for loss of child ${ }^{\text {xxvi }}$.

In the circumstances prevalent in the period, limited maternity care and high infant mortality were the immediate context in which poetry of child loss, and devotional elegy were composed $^{\text {xxvii }}$. It was either a mother consoling herself for the loss of her children, in or outside of the womb, or there were writings by women meant for the care and upbringing of their children's future, in the probable event of their death in childbirth. The birth of a child is a spiritual rebirth of a woman (and man), and therefore their recordings for their children are spiritual testimonials to transformation that is being imagined and recorded in the possibility of death in the process of birthing.

The following poem by Aphra Behn falls in the same tradition:

Epitaph On the Tombstone of a Child, the last of Seven that died before.

This Little, Silent, Gloomy Monument, Contains all that was sweet and innocent;

The softest pratler that e'er found a Tongue, His Voice was Musick and his Words a Song; Which now each List'ning Angel smiling hears, Such pretty Harmonies compose the Spheres;

Wanton as unfledg'd Cupids, ere their Charms

Had learn'd the little arts of doing harms;

Fair as young Cherubins, as soft and kind, And tho translated could not be refin'd;

The Seventh dear pledge the Nuptial Joys had given, Toil'd here on Earth, retir'd to rest in Heaven;

Where they the shining Host of Angels fill, Spread their gay wings before the Throne, and smile. ${ }^{\text {xxviii }}$

In the poetry of Carey, and occasional poems by Katherine Philips, Aphra Behn, Ben Jonson, amongst others, death of infants became occasions for the self to face spiritual crises. Besides the publicly available consolation poetry, we are certain of the trend of privately circulated poetry in 
diaries and letters as well as funeral sermons for departed children ${ }^{\mathrm{xxix}}$. In this context, the poetry of Anne Rhodes ${ }^{\mathrm{xxx}}$ is significant for it conjoins child mortality with human mortality itself and insists on seeing love as necessarily transcending form itself. In her poetry, one sees a therapeutic mode that reifies loss and grief into unattached love and leads to a graceful acceptance of mortality, a mode evident in the many poems of John Donne.

The poetry of Mary Carey offers an important dimension to see love. In her poetry, we are reminded to see the most beautiful extent of human love that mirrors the love of Christ for mankind in its selflessness and deliverance-the love of a mother (parent) for her child. The seemingly consolatory verses of Carey are profound poems exploring the extensions of human love that are embodied in the love of a mother for her child and the arrest of expression of that love in the event of the death of the child. For a Christian soul extending the love of Christ to fellow human beings, birthing a human being in its purest form is a crucial part of the whole human enterprise. The inability to do so, for whatever reasons, is naturally considered a failure. The consequent spiritual crisis manifests itself often in the form of guilt. The devotional writing of Mary Carey is full of details regarding her 'conversion'-from a life of indulgence to piety. The ensuing guilt on the death of children in womb or outside forms an integral part of this conversion narrative. In the poetry of Carey, there is a sense of complete surrender to the will of god, and the subject's desire to transcend worldliness by becoming one with god's love. In this endeavour, the death of her children can be seen in two ways: as a reminder, and as a sacrifice.

The lines "A Perigrene; my God me sent/him back againe I doe present" are lines of surrender written by an enabled subject who assumes semblance with Christ's sacrifice and 'presents' god himself with a gift-that of an innocent soul. In this context, it is interesting to see how Carey finds resonance in Marian theology even while submitting primarily to Christ. The 'return' of the present evokes the figure of Mother Mary, the mother of Christ himself, and her sacrifice of her son provides metaphorical healing through Carey's sacrifice of her own son.

The apparent meaning is of surrender of the human will to god in the image of a return of a beautiful present. However, the suggested meaning is not a conventional consolation, but a spiritual transformation. The subject is presenting her gift back to God, and in asserting authority over the present (the child), she is also asserting the authority of motherhood. To the mother, the child belongs in a way that is difficult to describe. This is a kind of assertion of the individual's person in relation to the person of god. To me, Carey's poetry seems more empowered than most anthologies would have us believe. The act of surrender in devotion is not a monolithic concept. The transformation of the passive subject to an enabled one is the point of real 'conversion' in Carey's poetry. This conversion offers a motif of healing in recognition of the act of giving as being a positive act, freeing the subject from a passive state of suffering.

\section{Paternal Elegies}

It is important to remember that this period also offers memorable poetry written by men over loss of their children. Along with Mary Carey's powerful poems, there were lines penned by her husband too:

Written by my dear Husband at ye Death of our $4^{\text {th }}$ (at that time) only Child, Robert Payler

1. Dear wife, let's learne to get that Skill, Of free Submission to God's holy Will; 
2. He like a Potter is; \& we like Clay, Shall not ye Potter mould us his own Way?

3. Sometimes it is his Pleasure that we stand With pretty lovely Baby's in our hand:

4. Then he in wisedome turns ye Wheel about, And drawes ye Posture of those Comforts out;

5. Into another Forme; either this, or that As pleases him; \& 'tis no matter what:

6. If by such Changes, God shall bring us in

To love Christ Jesus, \& to loath our Sin.

The Protestant motifs of sin and repentance abound in this poem. The use of plural personal pronoun distinguishes this poem from the consolatory verse of Mary Carey. The act of mutual participation and shared loss in a poetic address to the grieving mother as this, reiterates the importance of intergender dialogue in trauma as a therapeutic intervention.

A noted playwright of his period, Ben Jonson (1572-1637) has composed two moving poems on the death of his son and daughter. I find it relevant to share them here.

On my first Daughter

Here lyes to each her parents ruth,

Mary, the daughter of their youth:

Yet, all heavens gifts, being heavens due,

It makes the father, lesse, to rue.

At sixe moneths end, shee parted hence

With safetie of her innocence;

Whose soule heavens Queene, (whose name she

beares)

In comfort of her mothers teares,

Hath plac'd amongst her virgin-traine:

Where, while that sever'd doth remaine,

This grave partakes the fleshly birth.

Which cover lightly, gentle earth.

On my first Sonne

Farewell, thou child of my right hand, and joy;

My sin was too much hope of thee, lov'd boy.

Seven yeeres tho'wert lent to me, and I thee pay,

Exacted by thy fate, on the just day.

$\mathrm{O}$, could I loose all fathe, now. For why

Will man lament the state he should envie?

To have so soon scap'd worlds and fleshes rage,

And, if no other miserie, yet age?

Rest in soft peace, and, ask'd, say here doth lie

Ben Jonson his best piece of poetrie. 
For whose sake, hence-forth, all his vows be such,

As what he loves may never like too much.

I have quoted these poems to insist that spiritual crises is not gender specific, though it may be expressed and shared in gender specific contexts. ${ }^{\text {xxi }}$ Critical studies have focused on the identity, freedom and place of women devotional writers of Renaissance, and have also explored the important relationship between women writing poetry and an emerging readership for their poetry $^{\mathrm{xxxi}}$. However, it is worthwhile to look at the spiritual crises of parenthood ${ }^{\mathrm{xx} x i i}$ as a whole. Studying parental bereavement and the coping techniques, even while recognizing the specific emotive experience of women and men can be more applicable in the present contexts when gender roles have come to assume a marked difference from the early modern period ${ }^{\mathrm{xxxiv}}$.

The consolation poetry as that of Mary Carey can be studied as providing central motifs to the literature of therapy. The Protestant piety that heavily informs her writing must necessarily be seen in its relationship to the female experience. Her piety points to an innate power in the human experience that is enabling in providing natural and slowly realized therapeutic mechanisms. Whether in the consolation poetry of the Buddhist theris (nuns) or early modern English women, we find a spiritual leap that clearly states that motherhood in all its stages is a spiritual journey and all milestones on this journey are designed to impart lessons. From a theri who would weep at the cremation ground where her infant daughter was offered to the fires to Lady Carey who offers her own son 'back to God', we have poetic motifs and tropes to understand that liberation is a human right and a woman is gifted with multiple opportunities at it. Piety and prayer is therefore central to any complete understanding of mental health for women.

\section{The Trauma of Childlessness}

Along with the spiritual crisis of death of children, another important aspect of living that found a place in devotional writing of this period-was the condition of childlessness. For women like An Collins, due to ill health, child bearing was not a possibility; therefore in her writing, one comes across a search for Christian ways of making peace with this situation. In the absence of economic independence, childlessness would have been a way of social subordination for women. The responses to such socially constructed subjugation did find a voice in poetry, where an individual could engage in a conversation with god to understand and accept one's situation in life.

In a study titled 'Childless men in early modern England', Helen Berry and Elizabeth Foyster have researched the social position of men in the circumstance of inability to father a child. They comment:

It was a widely repeated maxim in early modern England that children were a providential blessing from God, an idea that was reinforced through the divine injunction in Genesis to procreate, the biblical precedent for regarding pregnancy as a mark of God's favour (which was apparently possible even in extreme old age), and Christ's blessing upon children, even though he himself was unmarried and childless. ${ }^{\mathrm{xxv}}$

Medical literature in sixteenth and seventeenth century relied heavily on the idea of man as

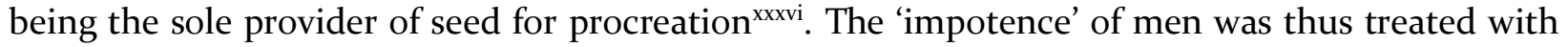
graveness where detailed analyses were made for the anatomical and other conjunctive reasons responsible for the loss of seed. With the then established notion of women as receptacles of men's seed, there were treatises discussing the barrenness of the womb wherein the relationship between 
body fat, heat and sexual pleasure were understood as the principal causes of women's infertility ${ }^{x x v i i}$. In addition to these medical texts, there were theological tracts and women's chapbooks that recognized the hand of God in the condition of infertility and both Protestant and Catholic theologies of the body accepted the sinfulness of human beings as being the principal source of this.

In understanding modern masculinity, a study of men's literature of childlessness can bring illuminating dimensions. These dimensions will enable us to understand the socially sanctioned and popularly accepted relationship between virility and fatherhood as being central to masculinity. It will also enable us to ponder on the consolation poetry of men where they provide a glimpse into liberated masculinity where grief and loss ${ }^{\mathrm{xxx} x i i i}$ become the bridge connecting men and women in consolatory dialogues providing beautiful poetic tropes. This will also enable us to recognize dialogue as a key therapeutic mode and dialogue poetry as a genre that is enabling for gender studies, as for instance the oral dialogue tradition of African societies, captured beautifully by Okot p-Bitek in The Song of Lawino and Ocol (1966).

\section{Conclusion: Reflections on Mental Health}

In contemporary times, writings about illness have begun to get recognized for the healing potential embedded in them. The poetry of Anne Sexton and Mary Oliver, or the prose of Susan Sontag and more recently the brilliant memoir of Paul Kalanithi have carved a poetic space for illness narratives. In English literary historiography, the poetry of early modern female poets who drew our attention to the spiritual dimensions of motherhood has remained out of canon formation. In their poetry, we can establish an early study of mental health dimensions of this deeply transformative experience. In the Indian context, there are powerful verses by theris, Buddhist nuns whose songs have been compiled in Therigatha $\left(6^{\text {th }}\right.$ to $3^{\text {rd }} \mathrm{c}$. BCE). We find songs about the death of their children and how, ravaged by grief, these women found Buddha's words coming to them. His words "cut away the bonds of flesh" and the "repeated cycles of coming and going" as they put beautifully in their lyrics.

In mainstream medicine, research has shown that prayer and spiritual exercises and experiences have a direct impact on mother and child health ${ }^{\text {xxxix }}$. The medical writings on reproduction have come a long way from male seed and 'one-sex' models through 'Eve's sinfulness' and 'dry womb' theories to a time when spiritual and mental health of women are seen as intrinsically related to the process of procreation. In this long journey, women's postpartum mental health and miscarriage and missedbirth psychological health are beginning to get recognized as serious illnesses that require compassion and empathy at both personal and social levels.

This paper has been an attempt to highlight the lacunae in English maternal healthcare literature where popular theology to protomedical writings have largely focused on material outcomes of childbirth but have not paid enough attention to the non-outcomes of partum itselfabortion, still births or infertility. The language of medical textbooks has also been shaped by a desacralization of the female body, resulting in expressions as 'blighted ovum', 'empty sack' and other soulless terms that have made motherhood into a result oriented examination engendering a chain of anxiety and depression for mothers at every stage. The sixteenth century Reformer Raynalde ${ }^{\mathrm{xl}}$ offered us an early anatomical understanding of women's reproductive bodies wherein, unlike his Continental peers, he upheld the sacredness of the female body according it a special status in the process of creation itself. It is a worthwhile proposition that a survey of medical 
literature on losses in and of the womb would help us identify the religio-social points of rupture when the sacred and mysterious body started becoming a familiar and bodily entity and all accidents of birth becoming 'malfunctions of the womb'.

\section{Notes}

${ }^{i}$ Fissell 2004, 43-81.

ii Lanyer,Aemilia .(1611). Salve Deus Rex Judaeorum (Hail God king of the Jews), Leigh, Dorothy. (1616). The Mothers Blessing

iii "The making of Protestant bodies desacralized the female reproductive body. Late medieval women were offered a vision of pregnancy and labor that briefly connected them to the divine by way of their identification with the Virgin Mary. Their bodies evoked wonder because the formative faculty of the womb seemed almost miraculous. Eventually the Reformation stripped female bodies of these connotations of wonder, and making babies became a physical process almost like any other", Fissell 2004,72.

iv See Pollock 1990, Long 2001, Gowing 2003, Brady 2006.

v See Allport 1963, 193: "The religious sentiment varies not only in depth and breadth, but also in its content and its mode of functioning. Indeed, since every personality is unique, [I have argued elsewhere that] the religious sentiment in every life must take a unique form."

${ }^{\text {vi }}$ In more contemporary sources she is dated as belonging to the fourteenth century.

vii Molekamp points to the relationship between confinement, piety and reading as essentially controlled by men who determine spaces such as the sickbed, prayer closets, who proclaim piety as an innate feminine virtue and who author/compile women's prayer books and teach them as ministers. See Molekamp 2012.

viii See Hirsch, John C. (1989). The Revelations of Margarey Kempe: Paramystical Practices in Late Medieval England. Brill.

ix The memoirs of Mrs. Alice Thornton of East Newton and Mrs. Ann Hulton are notable in recording the travails of childbirth, stillbirths and death of infants.

${ }^{x}$ Pratt 2010. 70 discusses The Book of Margarey Kempe as a primary source of women's writing on childbirth for "its utility is in providing personal attitudes that mirror the ambivalence of the individual and society to childbirth."

${ }^{x i}$ Gottlieb, Sidney (Ed.). (1996). Divine Songs and Meditacions.Arizona State University Press.

xii Stevenson, Davidson. (2001). Early Modern Women Poets (1520-1700). Oxford University Press, 337.

xiii Shapiro, Woodring(Eds.). (1994). The Columbia History of British Poetry.

xiv Greer, Germaine (Ed.). (1988). Kissing the Rod: An Anthology of Seventeenth-century Women's Verse. Virago, 148.

${ }^{x v}$ The practice of meditation popularized through the writings of St.Francois de Sales (1567-1622).

xvi The word "womanly" refers to the practices desired of a woman in this period-domestic work, and the duties becoming a married woman, especially birthing and raising children. "Unable to participate in normal female employments she turned first to 'prophane Histories' and then to 'Theological employments' in the form of poetry." (Greer, 148).

xvii Greer, 153. 
xviii Greer, 153-154.

${ }^{\text {xix }}$ Greer,154.

${ }^{x x}$ For a detailed study of typological poetics and the Protestant lyric, see Lewalski 1979. In this study, focus remains on the major religious poets of the seventeenth century: John Donne, George Herbert, Henry Vaughan, Thomas Traherne, and Edward Taylor. Lewaslki has paved the way for a close study of women's religious lyric and Protestant poetics in affect studies as undertaken by Molekamp 2010.

xxi For a detailed study of endogenous and exogenous causes of infant mortality in this period, see Webster, Charles. (1979). Health, Medicine and Mortality in the Sixteenth Century. Cambridge University Press.

xxii Wilcox,461.

xxiii Greer,156.

${ }^{\text {xxiv }}$ http://libres.uncg.edu/ir/uncg/f/M Dowd Genealogical 2012.pdf accessed on March 14, 2015

xxv There was a proliferation of socio-medical tracts on birthing and associated aspects like The byrth of mankind (1540), Childbirth or the happy delivery of women (1634), The Expert Midwife (1637), Directory for Midwives (1651), The Woman's Counsellor or The Female Physician (1664), The Midwife's Book (1671) in this period. There was also a proliferation of Christian prayers for women in labour and their assistants.

xxvi William Perkins' A Salve for a Sicke Man (1595) was very popular and he dedicated it to, besides mariners and soldiers, to "women when they trauell of child". However, there are no prayers, tracts or chapbooks dedicated to the post-partum psychological health of women, especially in the circumstances of foetal or infantile mortality.

xxvii The actual rates of maternal and infant mortality have remained a subject of discussion in critical studies. While Schofield (1986) argues for a non-exceptional maternal mortality rate in pregnancy and childbirth, Shorter (1982) and Eccles (1982) have argued for rather high maternal and foetal/infant mortality rates in the early modern period. In the context of limited or no records owing to the Church's demands of baptism and time limitations, the literary expressions of feared and actual mortality compel us to understand the affective and spiritual potential of the circumstances and events.

xxviii Greer, 258.

xxix In the public sphere, there was also the prevalence of tombs designed especially for death of women in childbirth or the death of children (or both). For a detailed study of this aspect, see Hertig 1983.

xxx Molekamp (2010) has discussed and printed some private poems of Anne Rhodes that were printed in the funeral sermon for her and her husband by Peter Samwaies, The Wise and Faithful Steward (London, 1657).

xxxi Stanley E. Porter has pointed to many translations of Psalms in this period in gender specific contexts, thereby creating an apologetic cult of the mother Eve: "In highlighting the specifically female character of this experience ,the use of apparently 'inclusive' language works to exclude men. This strategy emphasizes women's 'difference' as by isolating their experience it identifies them as Other to the male 'norm'. Feminizing the Pslams in this explicit manner, therefore, actually accentuates women's exclusion from religious language in general." Porter, Stanley E. Nature of Religious Language. N.p.: A \& C Black, 1995. 275.

xxxii See Kinney, Clare R. Introduction. Ashgate Critical Essays on Women Writers in England, 1550-1700: Volume 4. Lilley, Kate. “True state within: Women's elegy 1640-170o.” Women, Writing, History: 1640-1740. Eds. Isobel Grundy and Susan Wiseman. Athens: University of Georgia Press, 1992. 72-92.

xxxiii As dangerous as the feminizing of the Psalms as pointed out by Porter, is the feminization of criticism, that, while attempting to delve into the problems of female living, ends up isolating the feminine experience, creating a dichotomous, mutually exclusive universe, thereby drawing resentment from male readership and scholarship. The practice of isolating, making sacred and guarding the discourse of femininity altogether has often seen to be counterproductive and reductionist. 
xxxiv Woods (2006). 99-100 points out how due to medical advancements and an empirical view of pregnancy, the studies of bereavement and emotions have remained the focus of psychology but have slipped away from literary and anthropological focus. It is with the advancements in affect studies in the recent times that emotional aspects of childloss are being taken seriously.

xxxv Helen Berry and Elizabeth Foyster. (2007). The Family in Early Modern England. Mass: Cambridge University Press. 165.

xxxvi For a detailed study of fertility and early modern medical literature, see Jennifer Evans. (2014). Aphrodisiacs, Fertility and Medicine in Early Modern England. Boydell \& Brewer Ltd.

xxxvii See Culpeper, Nicholas. (1676). Culpeper's Directory for Midwives (1676), Platter, Felix. (1662). A golden practice of physic.

xxxviii For a close study of masculinity and emotions in the early modern period, see Vaught, Jennifer C. (2008). Masculinity and Emotion in Early Modern English Literature. Ashgate.

xxxix 'Spiritual and religious worldviews can shape parents' approaches to all aspects of having and raising children, including family planning, pregnancy, childbearing, postpartum experience, the feeding and care of an infant, child rearing and images of fatherhood and motherhood." Barnes et al, 901.

${ }^{\mathrm{xl}}$ Raynalde, The Byrth .

\section{References}

Allen, Phyllis. 'Medical Education in $17^{\text {th }}$ Century England', Journal of the History of Medicine and Allied Science, January 1946, Vol.1, No.1, pp.115-143.

Allport, Gordon W, 'Behavioral Science, Religion and Mental Health'. Journal of Religion and Health, Vol.2, No.3 (Apr., 1963), pp.187-197.

Anselment, Raymond A. “A Heart Terrifying Sorrow': An Occasional Piece on Poetry of Miscarriage.” Papers on Language \& Literature 33.1 (1997): 13-46.

---. “The Teares of Nature': Seventeenth-Century Parental Bereavement.” Modern Philology 91:1 (1993): 2653.

Atkinson, Clarissa. (1983). Mystic and Pilgrim: The Book and the World of Margarey Kempe.

Brady, Andrea. (2006). English Funerary Elegy in the Seventeenth Century. Palgrave Macmillan.

Crawford, Patricia. "The construction and experience of maternity in seventeenth-century 68 England."

Fildes, Valeria (Ed.). (1990). Women as Mothers in Pre-Industrial England. Routledge. 3-38.

Eccles, Audrey. (1982). Obstetrics and Gynaecology in Tudor and Stuart England. Croom Helm.

Gowing, Laura. (2003). Common Bodies: Women, Touch and Power in Seventeenth-Century England. Yale University Press.

Hammons, Pamela. "Despised Creatures: The Illusion of Maternal Self-Effacement in Seventeenth-Century Child Loss Poetry." ELH 66.1 (1999): 25-49.

Lochrie, Karma. Margarey Kempe and Translations of the Flesh. University of Pennsylvania Press, 1994.

Long, Donna J. “It is a lovely bonne I make to thee': Mary Carey's 'abortive Birth' Recuperative Religious Lyric." Discovering and (Re)Covering the Seventeenth Century Religious Lyric. Eugene R. Cunnar and Jeffrey Johnson (Eds.). (2001). Duquesne University Press. 248-72.

Neil, Kelly M., M.A. “Doe, As I Have Done:” Mary Carey’s Reciprocal Relationship with the Divine. (2006), Greensboro (unpublished thesis) 
Molekamp, Femke, 'Early Modern Women and Affective Devotional Reading', European Review of History, Vol.17, 2010- Issue 1: The Passions in European Political Thought and Literature 1600-190o.

-----, 'Seventeenth-Century Funeral Sermons and Exemplary Female Devotion: Gendered Spaces and Histories', Renaissance and Reformation, WINTER 2012, Vol.35, No.1, Special Issue: Gendering Time and Space in Early Modern England, pp.43-63.

Pollock, Linda A. "Embarking on a rough passage: the experience of pregnancy in early modern society." Women as Mothers in Pre-Industrial England. Fildes, Valerie. (1990). Routledge. 39-67.

---------. (1984). Forgotten Children: Parent-Child Relations from 1500 to 1900. Cambridge University Press.

PrattLa,D. 'Childbirth Prayers in Medieval and Early Modern England'. Symposia: The Journal of Religion, 2010. Accessed at file:///C:/Users/Administrator/Desktop/7352-Article\%20Text-25603-1-10-20100408.pdf on 1 September 2020.

Schofield, Roger, and E. A. Wrigley. "Infant and child mortality in England in the late Tudor and early Stuart period." Webster, Charles. (1979). Health, Medicine and Mortality in the Sixteenth Century. Cambridge University Press. 61-96.

Hurtig, Judith W. 'Death in Childbirth: Seventeenth-Century English Tombs and Their Place in Contemporary Thought'. The Art Bulletin, Vol.64, No.4 (Dec., 1983), pp. 603-615.

Linda L. Barnes, Gregory A. Plotnikoff, Kenneth Fox, Sara Pendleton. 'Spirituality, Religion, and Pediatrics: Intersecting Worlds of Healing', PEDIATRICS Vol. 104 No. 6 October 2000.

Schofield, Roger. 'Did the mothers really die? Three centuries of maternal mortality in "The world We Have Lost"' Bonfield et al (Eds). (1986). The World We Have Gained: Histories of Population and Social Structure. Basil Blackwell. 131-6o.

Shorter, Edward. (1982). A History of Women's Bodies. Basic Books.

Wilcox, Helen. “My Hart is Full, My Soul Dos Ouer Flow”: Women's Devotional Poetry in SeventeenthCentury England'. Huntington Library Quarterly, Vol. 63, No. 4, Forging Connections: Women's Poetry from the Renaissance to Romanticism (2000), pp. 447-466.

Woods, Robert. (2006). Children Remembered: Responses to Untimely Death in the Past. Liverpool University Press.

Dr. Namrata Chaturvedi is Associate Professor, Department of English, SRM University Sikkim. She holds a postdoctoral fellowship on 'Society and Religion in Asia' funded by Hong Kong University, Indonesia Consortium forReligious Studies and Asian Center for Cross Cultural Studies. Her areas of research include women's spiritual writings, religion and literature and Sanskrit literature. She has edited the volume titled Memory, Metaphor and Mysticism in Kalidasa's Abhijnanashakuntalam (London:Anthem Press, 2020). Her papers have been published in journals like The International Journal of Asian Christianity (Leiden: Brill), Yeats Journal of Korea (Seoul), IUP Journal of Commonwealth Literature and others. 